\title{
Towards an Integrative View of Innovation in Food Sector SME's
}

\begin{abstract}
Most literature on innovation focuses on organizational engagement with innovation types in isolation from one another. By establishing the interdependency of innovation types in SME's in the UK food sector, the study provides evidence to support the case for a more holistic approach in innovation research. As such, the study both contributes to the limited research on innovation in food sector SMEs and supports the integrative view of innovation. Using questionnaire-based data, Structured Equation Modelling was used to propose and test the inter-relationships between level of engagement with product, process, position and paradigm innovation. A significant positive relationship between innovation types was identified.
\end{abstract}

Keywords: Innovation types; Integrative innovation; Food sector; Small and mediumsized enterprises; SME’s.

\section{Introduction}

Innovation is recognized to play a central role in creating value and sustaining competitive advantage. Bessant et al. (2005) suggest that innovation is the core renewal process for organizations, whereas Damanpour et al. (2009) view innovation as key to changing the organization in order to maintain or improve its performance in dynamic marketplaces. However, whilst innovation is important, it is also a complex process, and, in addition, optimal innovation management routines are not easy to acquire . Furthermore, research into innovation in small enterprises and also into the food sector, is limited. This is surprising, given the importance of both small and medium sized enterprises (SMEs) (De Jong and Marsili, 2006; Forsman, 2011) and of 
the food sector (Avermaete, 2004; European Commission, 2012; Menrad, 2004) to economic development. The role that SMEs play in economic development has led to many government initiatives focused on encouraging innovation in SMEs . Similarly, for the food sector, innovation is deemed to be one of the most important factors in enhancing its competitiveness . Further, sector-based studies are recognised to be important in innovation, because there is evidence to suggest that sectoral characteristics influence innovation development, in general (Pavitt, 1984), and more specifically in SMEs (De Jong and Marsili, 2006; Forsman, 2011).

The specific focus of this study lies in the relationships between types of innovation. Many authors have recognized the importance of innovation type, category or dimension to the development of understanding, knowledge and theory relating to innovation (e.g. Damanpour and Evan, 1984; Francis and Bessant, 2005; Knight, 1967; Pavitt, 1984; Sawhney et al, 2006). However, much of the body of research on innovation, and in particular on innovation in SMEs tends to be restricted to certain types of innovation, such as open innovation, product innovation ), and technological innovation (Lin and Chen, 2007). Furthermore, the multiple taxonomies of innovation types, together with their diverse terminologies, hinder the development of a coherent body of knowledge on innovation. Whilst the existence of multiple taxonomies reflects the complex nature of innovation, the overlap between different taxonomies and their dimensions complicates the understanding of innovation. Accordingly, we select one taxonomy proposed by Bessant and Tidd (2007), that includes product, process, position and paradigm innovation, as the basis for this study, and proceed to explore the relationships between these types of innovation. In so doing, we seek to contribute to the emerging body of evidence regarding the importance of the interdependencies between types of innovation (e.g. Amara et al, 
2009; Wischnevsky et al, 2011), and the argument for an integrative view of innovation. The integrative view has the potential to complement the traditional approach in which research typically focuses on one or two types of innovation alone . Such an integrative approach is likely to be most valuable in SMEs in which innovation 'may be integrated into their daily business, customer collaboration and process optimization... and may be "hidden" even for the innovators' (Forsman, 2011, p. 741). A study of the applicability of the integrative view of innovation is important as it highlights the path for future research and practice. As such, confirmation of this view implies that innovation types should be studied and adopted in tandem with one another. However, one of the limitations of the integrative approach is that in practice it is not always possible to research all types of innovation simultaneously, since they might not all be occurring at the time of any given study, or the researcher may not have access to information on the full portfolio of innovations occurring in an organisation.

This research, then, has two aims:

1. To contribute to knowledge regarding innovation in food sector SMEs by focusing on their engagement with different types of innovation.

This addresses the need to add to the limited research in the important context of food SMEs that comprises $99.1 \%$ of Europe's enterprises .

2. To contribute to theory regarding the integrative view of innovation by studying the relationship between engagement with product and process innovation as well as position and paradigm innovation, which have received less attention.

Identification of positive relationships between these types of innovation will highlight the need for a holistic approach to study/adopt types of innovation and 
contradicts the distinctive view of innovation.

Next, a literature review summarises previous research on innovation in the food sector and on innovation in SMEs, identifies key innovation taxonomies and prior knowledge on the relationships between innovation types, and concludes with hypothesis and model development. An outline of the methodology adopted, including the questionnaire design, data collection, and respondent profile follows. The Data Analysis and Model Testing section presents the structural equation modelling and provides a diagram on the relationship between types of innovation. The article concludes with Conclusions and recommendations.

\section{Literature Review}

\section{Innovation in the food sector}

The food sector was selected as the context of this study due to its economic importance. In this study, food sector refers to all those organizations that produce any type of food, ingredients or drink products including agrifood and manufacturers. The European Commission (2012) identifies the food sector as one of the largest manufacturing sectors within the European Union. Although the food industry has been regarded as low tech and less innovative in comparison to other sectors, this sector has been driven by a variety of different types of innovation, including product, process and service innovations and innovation is deemed to be one of the most important factors in enhancing competitiveness within the food sector .

The strong imperative for innovation in this sector has led to a body of research into innovation. Such research embraces topics such as: research and development ; networks and the supply chain ; innovative behaviour ; product and 
process innovation (Avermaete et al, 2004; De Jong and Vermeulen, 2006); and, technology . Nevertheless, commentators suggest that there is a need for further research, specifically in relation to the drivers of innovation, types of innovation, and innovation orientation .

\section{Types of Innovation in SMEs}

Although the central focus of research into innovation has been within large organizations, the widespread recognition of the importance of SMEs to economic development has led to a growing body of research into innovation in SMEs, coupled with calls for further research . More specifically, whilst a number of studies have focused on the types of innovation adopted in SMEs, previous research does not give a clear picture of the relationship between innovation types in this context. For example, Lin and Chen (2007)'s study of Taiwanese SMEs within the manufacturing and service sectors revealed that technological and marketing innovations were the major types of innovation adopted within firms. Oke et al. (2007)'s study revealed that SMEs not only develop more incremental innovations than radical innovations, but that they are also more engaged with product innovation than with process and service innovation. Forsman and Annala (2011) agree that incremental innovations are more common in micro and small enterprises than radical innovations, however, Massa and $\underline{\text { Testa (2008) }}$ noted that SMEs play an important role in developing radical innovations. Further, together with De Jong and Marsili (2006) identified that SMEs are more engaged with process innovations than with product innovations. More recently, Higón and Driffield (2011) study identified that $43 \%$ of UK exporters conduct product innovation, $27 \%$ conduct process innovations, and $21 \%$ engage with both product and process innovations. This is not consistent, however, with findings 
from De Jong and Marsili (2006). Finally, Avermaete et al (2003) did not find any differences between engagement with product and engagement with process innovation among micro and small enterprises in the food industry. In summary, most studies on innovation in SMEs focus on one or two types of innovation, such that research on the relationship between a wider range of types of innovation in SMEs is scarce. In addition, given the differences in industry sectors, the need for a sector specific approach in research within innovation has been emphasised . For example, while pharmaceutical organisations are technology intensive, the food sector is known to be a low-tech sector; such differences between sectors support the case for sector specific research on innovation. Furthermore, both Forsman (2011) and Wischnevsky et al (2011) observe that most past research on innovation types has been conducted within the manufacturing sector, and argue for further research within other sectors and contexts.

\section{Innovation taxonomies and the distinctive and integrative views of innovation}

In order to be able to explore the relationships between different types of innovation, it is first necessary to identify an appropriate taxonomy of innovation types. Traditionally, innovations have been classified on the basis of their degree or outcome. Degree refers to the newness or degree of novelty involved, captured in the binary categorization, radical or incremental. Innovation outcome taxonomies are based on the outcome or effect of the innovation process. The concept of open innovation which is exploration and exploitation of external and internal sources in development of innovations is not covered in this study as this study focuses on the outcome of an innovation process when referring to types of innovation not the process of its development. 
Many innovation outcome taxonomies have been proposed. In 1967, Knight proposed the following types of innovation: organizational structure, production process, people, and product/service. Binary models proposed in the 1970's and 1980's discuss, variously, administrative, technical, incremental, radical, product, and process innovations (e.g. Daft and Becker, 1978; Damanpour and Evan, 1984; Damanpour, 1991). Recent taxonomies seek to be all-embracing. For example, Oke et al. (2007) suggest the following taxonomy: product (including radical and incremental), service, and process (including administrative, service and production) and Francis and Bessant (2005) suggest a taxonomy that includes the following types of innovation:

- "Product innovation, changes in the things (products/services) which an organization offers,

- $\quad$ Process innovation, changes in the way in which things (products/services) are created and delivered,

- Position innovation, changes in the context in which products/services are introduced,

- $\quad$ Paradigm Innovation, changes in the underlying mental models which frame what the organization does."

Numerous innovation types and taxonomies of innovation types have been proposed, yet it is often difficult to differentiate one type of innovation from another as, for example, a product innovation may incorporate some aspects of position or process innovation. For example, if the aim is to develop a new product, and during new product development, a new manufacturing process is introduced, a process innovation is associated with the product innovation. This fuzziness leads to overlap between types of innovation and ultimately to the interdependency between innovation types. 
Whilst some researchers are still wrestling with creating an effective taxonomy of innovation types, others have explored the interdependencies between different innovation types and the extent to which the adoption of one type of innovation leads to adoption of another type. Wischnevsky et al. (2011) argues that an understanding of the relationship between innovation types is essential as it affects the process of change management within organizations. Damanpour and Aravind (2006) and Damanpour (2010) have proposed the integrative view of innovation which highlights the complementary and dependent nature of innovation types. This view suggests that innovation types should not be distinguished; the consequence is that it is important to study these inter-dependencies. The contrary view, which is prevalent in much of the prior research, is the distinctive view; this assumes that innovation types are independent of one another, and for example, the 'generation and adoption of product and process innovation are assumed to be determined differently by environmental and organizational factors'.

There are previous studies on relationships between types of innovation, but most have focused on the relationship between only two types of innovation, such as that between administrative and technical innovations (Damanpour and Evan, 1984; Ettlie, 1988) or product and process innovation. An exception is Wischnevsky et al. (2011)'s study that has identified product innovations are followed by technological and administrative innovations at the organizational level. In addition, previous studies do not explore any dependencies that involve position and paradigm innovation, or related concepts such as marketing, business model, or disruptive innovation, although their relationship with other organizational processes, such as marketing or entrepreneurship elements has been highlighted. For example, organizational factors and internal processes that affect market orientation which is 
associated with position or market innovation, have been studied, and market orientation has been linked to product innovation performance . On the other hand, whilst the various dimensions of paradigm innovation have been studied (for example, Comes and Berniker, 2008; Chesbrough, 2007; Gambardella and McGahan, 2010), research on its relationship with other types of innovation is scarce. Furthermore, Teece (2010) suggests that 'The paucity of literature (both theoretical and practical) on the topic is remarkable, given the importance of business design, particularly in the context of innovation.' (p. 192).

In summary, most studies on innovation type relationships have investigated the pattern of adoption of innovations between two types of innovation among large organizations, in both the service and manufacturing sectors . Also, little attention has been directed towards position and paradigm innovation. Thus, in accordance with the above literature, we adopt the integrative view of innovation and propose the following hypotheses, which are founded on Francis and Bessant (2005)'s taxonomy of innovation (see Figure 1):

H1: There is a direct positive relationship between engagement in product and engagement in process innovation.

H2: There is a direct positive relationship between engagement in product and engagement in position innovation.

H3: There is a direct positive relationship between engagement in product and engagement in paradigm innovation.

H4: There is a direct positive relationship between engagement in process and engagement in position innovation.

H5: There is a direct positive relationship between engagement in process and engagement in paradigm innovation. 
H6: There is a direct positive relationship between engagement in position and engagement in paradigm innovation.

\section{Methodology}

\section{Research approach}

A questionnaire survey distributed to owners and managers in SMEs in the food sector in the UK was used to gather data on engagement with different types of innovation, to provide the potential for analysing the relationships between engagement with different types of innovation. Questionnaires were selected as a data collection method because they are suitable for gathering a large amount of data . A quantitative research method is suitable for measuring phenomena and is the main method of data collection in various previous studies. This approach enables this study to generalize in identifying the relationship between the level of engagement with the types of innovation in SMEs in the food sector.

\section{Questionnaire design and item generation}

Innovation has often been measured on the basis of input and output variables (i.e. R\&D expenditure, number of patents registered, number of new products, sales or turnover) . A number of researchers question the applicability of these measures especially in low-tech sectors and SMEs. Traill and Meulenberg (2002, p. 15) state that 'traditional measures of the number of new products introduced or share of revenue from new products are woefully inadequate particularly because they fail to differentiate the degree of novelty of the innovations'. Consequently, in this research innovation is measured on the basis of organizational engagement with innovation activities and processes associated with each innovation type, as adopted by Zahra and 


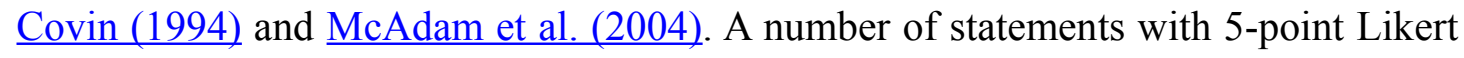
scales were generated to measure the four constructs, product, process, position and paradigm innovation as summarized in Table 1.

The four constructs include questions on level of engagement with the development of radical and incremental product, process, position and paradigm innovation and the level of resource allocation to each of these innovation types as this reflectsthe level of organizational focus and commitment. In addition, as shown in Table 1, a number of questions specific to each innovation type were included that characterized organizational engagement with the specific type of innovation. For example, for position innovation, four statements were included to cover engagement with branding, marketing and promotions, e-marketing and Customer Relationship Management .

In addition to the constructs, a number of questions on organizational characteristics were included in the questionnaire to profile the sample and its respondents, including: year of establishment, product range, and size (in terms of number of employees). Respondents were people with managerial positions within SMEs, who were assumed to be aware of their firm's strategies, business model, plans and organizational culture, and to be in a good position to comment on their firm's innovations . This includes respondents with roles such as managing director, owner, director, development manager, and marketing director.

Insert Table 1 here.

Initial questionnaire testing was conducted by two other researchers and by BIC Innovation (business consultants and sponsors of this study). This was designed 
to ensure the robustness of the questionnaires, and its applicability and suitability, in terms of the appropriateness of the language and content of the questionnaire for the target audience of practitioners. The questionnaire was then piloted by distribution to five SMEs selected from BIC Innovation's clientele to further ensure its suitability. The only change made as the result of this process was the removal of a question on organizational finances as the respondents viewed it as being too intrusive.

\section{Data collection}

In order to optimize the response, the questionnaire was distributed to food sector SMEs (food and drink producers with employee size<250) via two channels:

- Online questionnaires on SurveyMonkey were distributed to firms in Wales and England through BIC Innovation's databases, and partner organizations of BIC Innovation (93 respondents).

- Questionnaires were distributed and collected by the lead author at a number of food festivals and exhibitions held throughout England and Wales (156 respondents).

221 usable questionnaires were collected. However, after excluding any questionnaires with more than ten percent missing data, 188 questionnaires remained and these were used in the analysis. To confirm that the two methods of data collection (online vs. exhibition) are compatible, chi-square test was conducted; no significant differences were identified between the two data sets. Data were first entered and coded in Excel, and then imported into SPSS 16 and Lisrel, for analysis.

\section{Findings}

\section{Respondents' Profile}

The majority of respondents $(68 \%, n=127)$ are micro firms (10 or fewer 
employees), 21\% $(n=40)$ are small (11-50 employees) and 11\% $(n=21)$ are medium sized firms (51-250 employees). This compares well with the size distribution of food manufacturers in the UK, where $64 \%$ of the firms are micro, $25 \%$ are small and $11 \%$ are medium . With regard to organizational age, there is a balanced distribution, with $35 \%$ having been established for five years or less, $42 \%$ for between 6 and 20 years, and $23 \%$ for 21 years of more. Finally, in terms of product group, $22 \%$ were engaged with beverages (such as alcoholic drinks, juices or hot drinks), 51\% with fresh food (farm related and other products sold fresh, such as meat and bread, 27\% with preserves (products with additives and preservatives, such as chutneys, sauces, and confectionary).

\section{Data Analysis and Model Testing}

To test the model presented in Figure 1, the psychometric properties of the scales used to measure the four latent constructs of the study were first established using inter-item correlations, tests of reliability, and both convergent and discriminant validity analyses of the four scales.

Insert Figure 1 here.

Inter-item correlations. The inter-item correlations were calculated for each set of items within each of the four scales as well as among the composites (averages) of the four scales. All were significantly inter-correlated within their corresponding scales $(p<.05)$. The average inter-item correlations for the scales were: Product Innovation $r=.55$, Process Innovation $r=.63$, Position Innovation $r=.60$, Paradigm Innovation $r=.55$. The average inter-scale correlation for the four composite scales 
was $r=.64$. All inter-item and inter-scale correlations in this study were all above the recommended value of $r=.3$ indicating a strong inter-relationship among the measurement variables for each of the four constructs as well as their composites.

Reliability. Scale reliability provides a measure of the internal consistency and homogeneity of the items comprising a scale ; it was calculated using Cronbach's alpha. As seen in Table 2, the reliability of the four scales ranged from $a=0.89$ to $a=0.91$ which is well above the recommended minimum of 0.7 , providing evidence supporting the reliability of the scales.

Insert Table 2 here.

CFA model fit. The four constructs were confirmed in a single CFA model (Long, 1983; Bollen, 1989). All aspects of the model were proposed a priori and no modification indexes or freeing of correlations $(t d)$ between errors were used to fit the model to the data. As recommended by multiple fit criteria are presented to evaluate the measurement model of the four constructs under investigation. The model's chisquare statistic was significant $\left(\chi^{2}=703.57 ;\right.$ d.f. $\left.=333 ; p<0.05\right)$. However, the chisquare estimate has been shown to be over-sensitive to small model discrepancies when the model contains a large number of variables (that is when the model is complex) (Byrne,1994; Hair et al, 1995). Thus, the LISREL model fit indices are

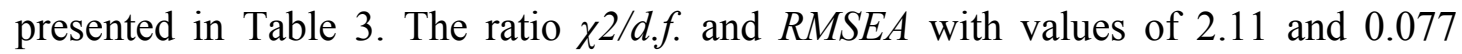
respectively were below the recommended maximum of 3.00 and 0.10 . Additionally, the indexes NNFI, CFI, NFI, NNFI and IFI were all above the minimum acceptable 0.90 level, with values of $0.97,0.97,0.96$ and $0.97,0.97$ respectively. Thus, there is strong evidence to indicate that the CFA model fits the sample data. 
Insert Table 3 here.

Convergent validity. Convergent validity is demonstrated when a set of alternative measures accurately represents the construct of interest . It was assessed reviewing the level of significance for the factor loadings using a confirmatory factor analysis (CFA) of the items of each of the four scales. If all the individual item's factor loadings are significant, then the indicators are effectively measuring the same construct and the construct is unidimensional. As reported in table 2, the standardized coefficients from the CFA of the 26 measurement variables in the four scales (product, process, position and paradigm) were moderately large and significant $(t$-values $>2.576 ; p<0.05)$. The results provide satisfactory evidence of convergent validity for the indicators used to measure each of the scales in this study.

Discriminant validity. Discriminant validity is assessed among the latent variables and their associated measurement variables by fixing (that is constraining) the correlation between pairs of constructs to 1.0 , then re-estimating the modified model. The condition of discriminant validity is met if the difference of the chi-square statistics between the constrained and standard models is significant $\left(\begin{array}{ll}1 & d . f .\end{array}\right)$. The chi-square difference tests, from each construct pairing, were all significant which indicates that discriminant validity exists among all of the four constructs in this study $(p<0.01)$ (see Table 4). Thus, each construct is measuring a distinct underlying latent variable. 
Insert Table 4 here.

\section{Hypotheses Testing}

All six hypotheses asserted a direct positive relationship between the constructs as reflected in figure 1, thus:

- H1: The correlation path relating the two constructs was positive and significant (standardized $\varphi_{1}$ coefficient $r=0.73 ; T$-value $=16.78 ; p<0.05$ ). Thus, there is a direct positive relationship between engagement in product and process innovation.

- H2: The correlation path relating the two constructs was positive and significant (standardized $\varphi_{2}$ coefficient $r=0.75 ; T$-value $=15.63 ; p<0.05$ ). Thus, there a direct positive relationship between engagement in product and position innovation.

- H3: The correlation path relating the two constructs was positive and significant (standardized $\varphi_{3}$ coefficient $r=0.69 ; T$-value $=15.51 ; p<0.05$ ). Thus, there a direct positive relationship between engagement in product and paradigm innovation.

- H4:. The correlation path relating the two constructs was positive and significant (standardized $\varphi_{4}$ coefficient $r=0.72 ; T$-value $=13.72 ; p<0.05$ ). Thus, there a direct positive relationship between engagement in process and position innovation.

- H5: The correlation path relating the two constructs was positive and significant (standardized $\varphi_{5}$ coefficient $r=0.77 ; T$-value $=17.66 ; p<0.05$ ). Thus, there a direct positive relationship between engagement in process and paradigm innovation. 
- H6: The correlation path relating the two constructs was positive and significant (standardized $\varphi_{6}$ coefficient $r=0.78 ; T$-value $=17.06 ; p<0.05$ ). Thus, there a direct positive relationship between engagement in position and paradigm innovation.

To conclude, this study has identified a direct positive relationship between all types of innovation through application of structural equation modelling on types of innovation. This confirms all of the hypotheses generated in this study, H1 to H6, and the model in Figure 1. These findings support the integrative view of innovation, at least to the extent that they confirm relationships between levels of engagement in different types of innovation.

\section{Discussion}

A positive relationship was found between engagements with four types of innovation among food sector SMEs. This suggests that development and adoption of one type of innovation is positively linked (leads) to development and adoption of other types of innovation. The findings support and validate the integrative view of innovation in the context of food SMEs. This implies that innovation types should not be studied or adopted in isolation from one another and the significant interdependencies between innovation types should be considered (Amara et al, 2009; Wischnevsky et al, 2011). In particular, whilst researchers may choose for operational reasons to focus on specific types of innovation, they should be aware of the potential inter-dependencies between innovation types, especially, but not necessarily exclusively in food SMEs. Moreover, SMEs could overcome their shortcomings in today's competitive markets by recognizing the link between innovation types, and focusing on encouragement of adding value by development and adoption of innovations in tandem. In addition, this study suggests that the rather under-researched topics of position and paradigm 
innovation require further study, if only because they are shown to affect process and product innovation. These findings suggest that an integrative view of types of innovation should be taken seriously, and that more research should be conducted to establish its wider applicability, and the consequences of this theoretical stance.

The positive relationship between innovation types agrees with Damanpour (2010) suggestion that a mix of innovation strategies embracing all types of innovation should be adopted within organizations. More specifically, this study confirms studies that propose relationships between types of innovation (for example, Amara et al, 2009; Damanpour and Gopalakrishnan, 2001; Wischnevsky et al, 2011). Furthermore, this research has both: moved beyond the aforementioned binary studies by considering all four types of innovation as proposed by ; and, added to the limited research on innovation within the context of SMEs and the food sector. Although the food sector has been considered a low tech sector, and hence less innovative in comparison to other industries, this study demonstrates that study of all types of innovation is applicable within this sector. In addition, this study highlights strong interdependencies between food SME's level of engagement with different innovation types. As such, one of the main contributions of this study is focusing on all four types of innovation within the context of food SMEs.

\section{Conclusion and recommendations}

An understanding of relationships between innovation types is useful both for management of change within organizations and for a better understanding of the commonalities and complementariness between innovation types. This study has proposed and tested an innovation type relationship model. A direct positive association between the four types of innovation included in the taxonomy of innovation proposed by Francis and Bessant (2005) has been identified, in the context 
of food sector SMEs in the UK.

This research suggests that in food SMEs different types of innovation are inter-dependent. Accordingly, managers need to be cognizant of this, and, plan and organize accordingly. Equally important, business consultants and other advisors involved in supporting the development of food SMEs should recognize the need to integrate different types of innovation, and in particular to promote a focus on the marketplace (position innovation) and the potential for changing business models and market positioning (paradigm innovation).

This research offers significant support for the integrative theory of innovation. This potentially undermines earlier research on innovation that has been restricted to one or two types of innovation, suggesting that it is only revealing part of the picture. As such, the findings of this research are an invitation to researchers to develop further empirical research and theory to explore and test:

1. The applicability of the integrative model of innovation to SMEs in other sectors

2. The applicability of the integrative model of innovation to larger organizations, which may have a more complex and diverse innovation strategy, executed through a variety of different departments, and sometimes in collaboration with other organizations.

3. The relationships between levels of integration of innovation and various business characteristics, including, business size, age, sector, performance and growth.

And to develop understanding of:

4. The dynamics of the relationship between the different types of innovation in different contexts. 
5. The way in which different types of innovation contribute to organizational innovation and business performance and growth. 


\section{Table 1}

\begin{tabular}{|c|c|c|}
\hline Construct & Item & Source \\
\hline \multicolumn{3}{|l|}{ Product } \\
\hline & Product1: & Francis and Bessant (2005), Tidd, Bessant, and Pavitt (2005) \\
\hline & Product2: & Francis, and Bessant (2005), Tidd, Bessant, and Pavitt (2005) \\
\hline & Product3: & $\begin{array}{l}\text { Clercq, Menguc, and Auh (2009), Cooper and Edgett (2010), } \\
\text { Siguaw, Simpson, and Enz (2006) }\end{array}$ \\
\hline & Product4: & Earle (1997), Sonneveld (2000), Olsson and Larsson (2009) \\
\hline & Product5: & Earle (1997), Sonneveld (2000), Olsson and Larsson (2009) \\
\hline & Product6: & Young (2004) \\
\hline & Product7: & Nambisan (2003) \\
\hline \multicolumn{3}{|l|}{ Process } \\
\hline & Process 1: & Francis and Bessant (2005), Tidd, Bessant, and Pavitt (2005) \\
\hline & Process 2: & Francis and Bessant (2005), Tidd, Bessant, and Pavitt (2005) \\
\hline & Process3: & $\begin{array}{l}\text { Van de Ven (1999), Cooper and Edgett (2010), Siguaw, } \\
\text { Simpson, and Enz (2006) }\end{array}$ \\
\hline & Process 4: & Francis and Bessant (2005) \\
\hline & Process5: & Davenport (1993), Mooney, Gurbaxani and Kraemer (1996) \\
\hline & Process6: & Ettlie and Reza (1992), Francis and Bessant (2005) \\
\hline \multicolumn{3}{|r|}{ (1) } \\
\hline & Position 1: & Francis and Bessant (2005) \\
\hline & Position2: & Francis and Bessant (2005) \\
\hline & Position3: & $\begin{array}{l}\text { Van de Ven (1999), Cooper and Edgett (2010), Siguaw, } \\
\text { Simpson, and Enz (2006) }\end{array}$ \\
\hline & Position4: & Doyle (1995), Doyle (2000), Francis and Bessant (2005) \\
\hline & Position5: & Doyle (1995), Doyle (2000), Francis,and Bessant (2005) \\
\hline & Position6: & $\begin{array}{l}\text { Whyte, Bessant, and Neely (2005), Francis and Bessant } \\
(2005)\end{array}$ \\
\hline & Position 7: & Homburg, Workman, and Jensen (2000), Fuglsang (2008) \\
\hline \multicolumn{3}{|r|}{ (3) } \\
\hline & Paradigm1: & Francis and Bessant (2005), Tidd, Bessant, and Pavitt (2005) \\
\hline & Paradigm2: & Francis and Bessant (2005), Tidd, Bessant, and Pavitt (2005) \\
\hline & Paradigm3: & $\begin{array}{l}\text { Van de Ven (1999), Siguaw, Simpson, and Enz (2006), } \\
\text { Chesbrough (2007) }\end{array}$ \\
\hline & Paradigm 4: & Francis and Bessant (2005), Tidd, Bessant, and Pavitt (2005) \\
\hline & Paradigm5: & $\begin{array}{l}\text { Francis and Bessant (2005), Trimi and Berbegal-Mirabent } \\
\text { (2012) }\end{array}$ \\
\hline & Paradigm6: & $\begin{array}{l}\text { Francis, and Bessant (2005), Trimi and Berbegal-Mirabent } \\
(2012)\end{array}$ \\
\hline
\end{tabular}


Table 2

Construct Reliability Estimates and Measurement Loadings

\begin{tabular}{|c|c|c|c|c|}
\hline Code & Construct / Item & Mean & SD & $\begin{array}{l}\text { tandardized } \\
\text { Loadings }\end{array}$ \\
\hline \multicolumn{5}{|c|}{ PRODUCT INNOVATION (Reliability $=0.89$ ) } \\
\hline Product1 & Incremental Product Innovation & 4.22 & 1.01 & $0.63 *$ \\
\hline Product 2 & Radical Product Innovation & 3.56 & 1.23 & $0.67 *$ \\
\hline Product3 & Incremental Packaging Innovation & 3.73 & 1.19 & $0.79 *$ \\
\hline Product4 & Radical Packaging Innovation & 3.03 & 1.36 & $0.90 *$ \\
\hline Product5 & Resource Product Innovation & 3.42 & 1.14 & $0.86^{*}$ \\
\hline Product6 & Resource Packaging Innovation & 3.14 & 1.27 & $0.89 *$ \\
\hline Product7 & IT for Products & 3.35 & 1.24 & $0.68 *$ \\
\hline \multicolumn{5}{|c|}{ PROCESS INNOVATION (Reliability =0.90) } \\
\hline Process 1 & Incremental Process Innovation & 4.07 & 0.92 & $0.70 *$ \\
\hline Process 2 & Radical Process Innovation & 3.46 & 1.23 & $0.86^{*}$ \\
\hline Process 3 & Resource Process Innovation & 3.27 & 1.17 & $0.88^{*}$ \\
\hline Process 4 & Performance Improvement Technique & 3.17 & 1.28 & $0.88 *$ \\
\hline Process 5 & IT for Process & 3.40 & 1.20 & $0.79 *$ \\
\hline Process6 & Develop New Technology & 3.25 & 1.28 & $0.85^{*}$ \\
\hline \multicolumn{5}{|c|}{ POSITION INNOVATION $($ Reliability $=0.91)$} \\
\hline Position1 & Incremental Position Innovation & 3.94 & 1.18 & $0.77 *$ \\
\hline Position2 & Radical Position Innovation & 3.56 & 1.22 & $0.78 *$ \\
\hline Position3 & Resource Position Innovation & 3.23 & 1.25 & $0.87 *$ \\
\hline Position4 & Branding & 3.38 & 1.33 & $0.90 *$ \\
\hline Position5 & Promotions & 3.48 & 1.29 & $0.88 *$ \\
\hline Position6 & eMarketing & 3.52 & 1.41 & $0.74 *$ \\
\hline Position 7 & $\mathrm{CRM}$ & 2.61 & 1.40 & $0.80 *$ \\
\hline \multicolumn{5}{|c|}{ PARADIGM INNOVATION (Reliability $=0.89$ ) } \\
\hline Paradigm1 & Incremental Paradigm Innovation & 3.81 & 1.08 & $0.80 *$ \\
\hline Paradigm 2 & Radical Paradigm Innovation & 2.98 & 1.22 & $0.86^{*}$ \\
\hline Paradigm3 & Resource Paradigm Innovation & 3.05 & 1.17 & $0.86^{*}$ \\
\hline Paradigm4 & Business Model & 3.48 & 1.20 & $0.87 *$ \\
\hline Paradigm5 & Partnering and Alliances & 2.94 & 1.28 & $0.74 *$ \\
\hline Paradigm6 & Mergers and Acquisitions & 2.52 & 1.34 & $0.65 *$ \\
\hline
\end{tabular}


Table 3

Summary of SEM Fit Indexes

\begin{tabular}{lcc}
\hline $\begin{array}{l}\text { Fit } \\
\text { Measures }\end{array}$ & $\begin{array}{c}\text { Recommended } \\
\text { threshold values }\end{array}$ & $\begin{array}{c}\text { Measured } \\
\text { values }\end{array}$ \\
\hline$\chi^{2}$ & $\geq 0.05$ & 731.01 \\
$p$ - value & & 0.000 \\
d.f. & $\leq 3.00$ & 293 \\
$\chi^{2} /$ d.f. & $\leq 0.10$ & 2.49 \\
RMSEA & $\geq 0.90$ & 0.089 \\
NNFI & $\geq 0.90$ & 0.97 \\
CFI & $\geq 0.90$ & 0.97 \\
NFI & $\geq 0.90$ & 0.96 \\
NNFI & $\geq 0.90$ & 0.97 \\
IFI & & 0.97 \\
\hline
\end{tabular}


Table 4

Assessment of Discriminant Validity of the Constructs

\begin{tabular}{|c|c|c|c|c|}
\hline Innovation Type Constructs & Correlation & $\begin{array}{c}\text { Correlation } \\
p \text {-value }\end{array}$ & $\begin{array}{c}\text { Chi-square } \\
\text { difference } \\
\text { (1 d.f.) }\end{array}$ & $\begin{array}{c}\text { Chi-square } \\
p \text {-value }\end{array}$ \\
\hline \multicolumn{5}{|l|}{ Product Innovation with } \\
\hline Process Innovation & $0.79 *$ & 0.000 & 213 & 0.000 \\
\hline Position Innovation & $0.77 *$ & 0.000 & 245 & 0.000 \\
\hline Paradigm Innovation & $0.72 *$ & 0.000 & 269 & 0.000 \\
\hline \multicolumn{5}{|l|}{ Process Innovation with } \\
\hline Position Innovation & $0.72 *$ & 0.000 & 318 & 0.000 \\
\hline Paradigm Innovation & $0.80 *$ & 0.000 & 178 & 0.000 \\
\hline \multicolumn{5}{|l|}{ Position Innovation with } \\
\hline Paradigm Innovation & $0.78 *$ & 0.000 & 167 & 0.000 \\
\hline
\end{tabular}

Full model constructs

* Correlation is significant at the $\alpha=0.05$ level (2-tailed) 
Figure 1

Structural equation model representing the inter-relationships of the four innovation constructs

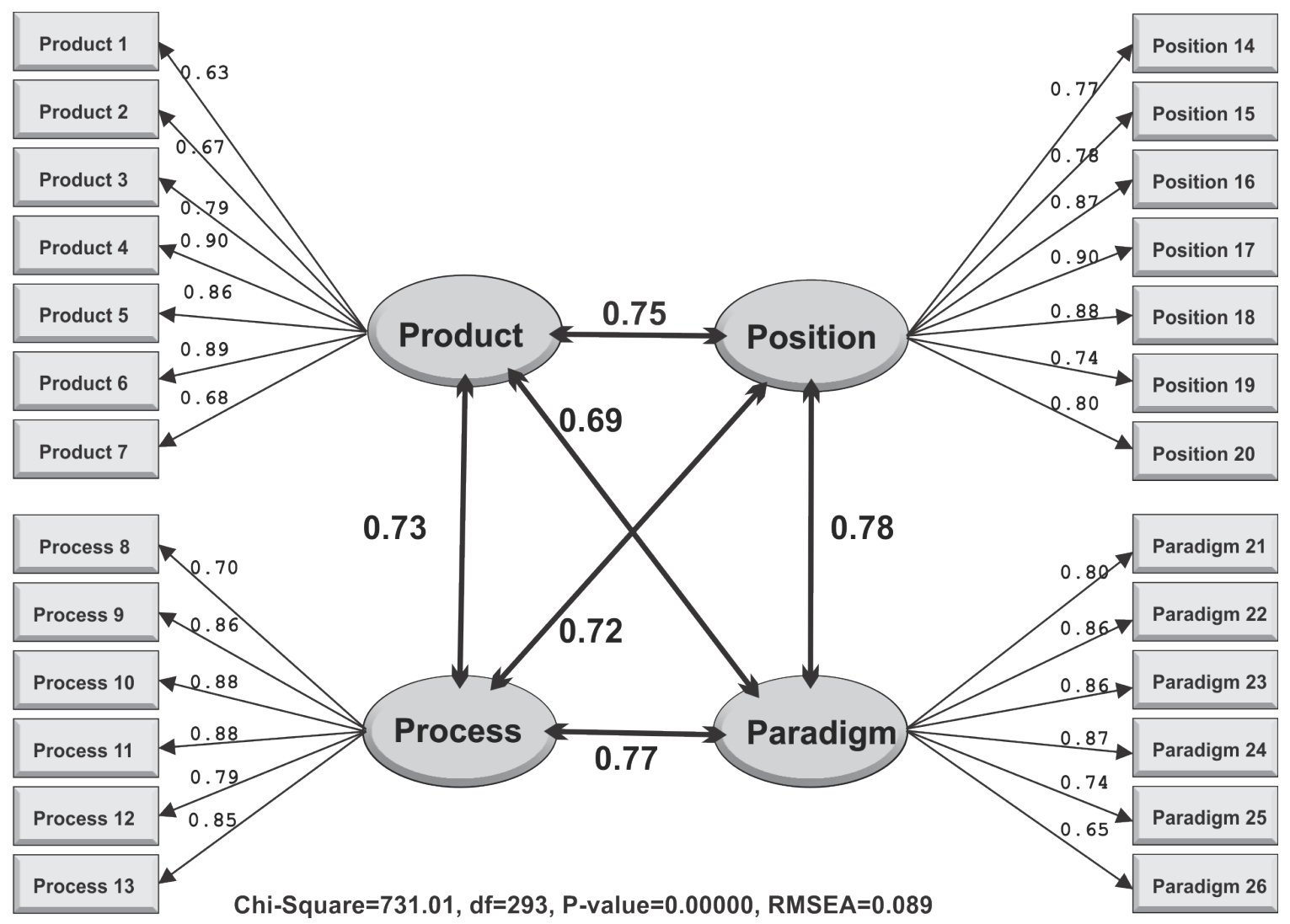

ADAMS, R., BESSANT, J. \& PHELPS, R. 2006. Innovation management measurement: A review. International Journal of Management Reviews, 8, 21-47.

ANDERSON, J. C. \& GERBING, D. W. 1984. The effect of sampling error on convergence, improper solutions, and goodness of fit indices for maximum likelihood confirmatory factor analysis. Psychometrika, 49, 155-173.

AVERMAETE, T. 2002. Systems of innovation: the case of small food firms in the EU. DRUID PhD Winter Conference. Aalborg, Denmark.

AVERMAETE, T., MORGAN, E. J., VIAENE, J., PITTS, E., CRAWFORD, N. $\&$ MAHON, D. 2003. Regional patterns of innovation: Case 
study of small food firms. DRUID Summer Conference on Creating, Sharing and Transferring Knowledge. Copenhagen.

AVERMAETE, T., VIAENE, J., MORGAN, E. J., PITTS, E., CRAWFORD, M. $\&$ MAHON, D. 2004. Determinants of product and process innovation in small food manufacturing firms. Trends in Food Science \& Technology, 15, 474-483.

BESSANT, J., LAMMING, R., NOKE, H. \& PHILLIPS, W. 2005. Managing Innovation beyond the steady state. Technovation, 25, 13661376.

BESSANT, J. \& TIDD, J. 2007. Innovation and Entrepreneurship, Chichester, John Wiley \& Sons.

BIGLIARDI, B. \& DORMIO, A. I. 2009. An empirical investigation of innovation determinants in food machinery enterprises. European Journal of Innovation Management, 12, 223-242.

BOUGHEAS, S. 2004. Internal vs external financing of R\&D. Small Business Economics, 22, 11-17.

BRYMAN, A. \& BELL, E. 2007. Business research methods, New York, Oxford University Press.

CAPITANIO, F., COPPOLA, A. \& PASCUCCI, S. 2010. Product and process innovation in the Italian food industry. Agribusiness, 26, 503-518.

CHAU, P. Y. K. 1997. Reexamining a model for evaluating information center success using a structural equation modelling approach. Decision Sciences, 28, 309-334.

CHRIS, R. 2012. Small businesses and the UK economy UK, House of Commons Library.

CHRISTENSEN, C. 1997a. The innovator's dilemma: when new technologies cause great firms to fail, Harvard Business Press.

CHRISTENSEN, C. M. 1997b. Innovator's Dilemma: When New Technologies Cause Great Firms to Fail, Boston, MA, Harvard Business School Press Books.

CHURCHILL, G. 1979. A paradigm for developing better measures of marketing constructs. Journal of Marketing Research, 16, 6473.

CLERCQ, D. D., MENGUC, B. \& AUH, S. 2009. Unpacking the relationship between an innovation strategy and firm performance: The role of task conflict and political activity. Journal of Business Research, 62, 1046-1053.

COOPER, J. R. 1998. A multidimensional approach to the adoption of innovation. Management Decision, 36, 493-502.

COOPER, R. G. \& EDGETT, S. J. 2010. Developing a Product Innovation and Technology Strategy for Your Business. Research Technology Management, 53, 33-40.

DAMANPOUR, F. 2010. An integration of research findings of effects of firm size and market competition on product and process innovations. British Journal of Management, 21, 996-1010.

DAMANPOUR, F. \& ARAVIND, D. 2006. Product and process innovations: A review of organizational and environmental determinants. In: HAGE, J. \& MEEUS, M. (eds.) Innovation, 
science, and institutional change. New York: Oxford University Press.

DAMANPOUR, F. \& EVAN, W. M. 1984. Organizational innovation and performance: the problem of "organizational lag".

Administrative Science Quarterly, 29, 392-409.

DAMANPOUR, F. \& GOPALAKRISHNAN, S. 2001. The dynamics of the adoption of product and process innovations in organizations. Journal of Management Studies, 38, 45-65.

DAMANPOUR, F., SZABAT, K. A. \& EVAN, W. M. 1989. The relationship between types of innovation and organizational performance. Journal of Management Studies, 26, 587-602.

DAMANPOUR, F., WALKER, R. M. \& AVELLANEDA, C. N. 2009. Combinative effects of innovation types and organizational performance: A longitudinal study of service organizations. Journal of Management Studies, 46, 650-675.

DAVENPORT, T. H. 1993. Process innovation: reengineering work through information technology, USA, Harvard Business Press.

DOYLE, P. 1995. Marketing in the new millennium. European Journal of Marketing, 29, 23-41.

DOYLE, P. 2000. Value-based marketing. Journal of Strategic Marketing, 8, 299-311.

DRIVAS, K. \& GIANNAKAS, K. 2006. The effect of cooperatives on product innovation in the agri-food system. American Agricultural Economics Association Annual Meeting. California.

EARLE, M. 1997. Innovation in the food industry. Trends in Food Science \& Technology, 8, 166-175.

ETTLIE, J. E. 1988. Taking charge of manufacturing, San Francisco, Jossey-Bass.

ETTLIE, J. E. \& REZA, E. M. 1992. Organizational Integration and Process Innovation Academy of Management Journal, 35, 795827.

FONTANA, R. \& GUERZONI, M. 2008. Incentives and uncertainty: an empirical analysis of the impact of demand on innovation. Cambridge Journal of Economics, 32, 927-946.

FOODDRINKEUROPE 2011. Supporting the competitiveness of the European food and drink industry.

FORTUIN, F. T. J. M. \& OMTA, S. W. F. O. 2009. Innovation drivers and barriers in food processing. British Food Journal, 111, 839-851.

FRANCIS, D. \& BESSANT, J. 2005. Targeting innovation and implications for capability development. Technovation, 25, 171-183.

FREEL, M. S. 2000. Barriers to Product Innovation in Small Manufacturing Firms. International Small Business Journal, 18, 60-80.

FUGLSANG, L. 2008. Innovation and the creative process: towards innovation with care, Cheltenham and Northampton, MA, Edward Elgar Publishing.

GRUNERT, K., HARMSEN, H., MEULENBERG, M., KUIPER, E., OTTOWITZ, T., DECLERCK, F., TRAILL, W. B. \& GOĖRANSSON, 
G. 1997. A framework for analysing innovation in the food sector. In: TRAILL, W. B. \& GRUNERT, K. (eds.) Product and Process Innovation in the Food Industry. London: Blackie Academic and Professional.

HAIR, J., ANDERSON, R., TATHAM, R. \& BLACK, W. 1995. Multivariate Data Analysis with Readings, Englewood Cliffs, NJ, Prentice Hall.

HAIR, J. F., ANDERSON, R. E., TATHAM, R. L. \& BLACK, W. C. 1998. Multivariate Analysis, Englewood Cliffs, NJ, Prentice Hall International.

HAIR, J. F., MONEY, A. H., SAMOUEL, P. \& PAGE, M. 2007. Research methods for business, West Sussex, John Wiley \& Sons West Sussex.

HIGÓN, D. A. \& DRIFFIELD, N. 2011. Exporting and innovation performance: Analysis of the annual Small Business Survey in the UK. International Small Business Journal, 29, 4-24.

HOMBURG, C., WORKMAN, J. P. \& JENSEN, O. 2000. Fundamental changes in marketing organization: the movement toward a customer-focused organizational structure. Journal of the Academy of Marketing Science, 28, 459-478.

HORTE, S. A., BARTH, H., CHIBBA, A., FLOREN, H., FRISHAMMAR, J., HALILA, F., RUNDQUIST, J. \& TELL, J. 2008. Product Development in SMEs: a literature review. International Journal of Technology Intelligence and Planning, 4, 299-325.

KARAPIDIS, A., KIENLE, A. \& SCHNEIDER, H. 2005. Creativity, Learning and Knowledge Management in the Process of Service Development-Results from a survey of experts. IKNOW Austria.

KIRCA, A. H., JAYACHANDRAN, S. \& BEARDEN, W. O. 2005. Market orientation: a meta-analytic review and assessment of its antecedents and impact on performance. Journal of Marketing, $69,24-41$.

KOHLI, A. K. \& JAWORSKI, B. J. 1990. Market orientation: the construct, research propositions, and managerial implications. The Journal of Marketing, 54, 1-18.

LAFORET, S. \& TANN, J. 2006. Innovative characteristics of small manufacturing firms. Journal of Small Business and Enterprise Development, 13, 363-380.

LIN, C. Y. Y. \& CHEN, M. Y. C. 2007. Does innovation lead to performance? An empirical study of SMEs in Taiwan. Management Research News, 30, 115-132.

LONG, J. S. 1983. Confirmatory Factor Analysis, California, Sage Publications.

LOVE, J. H. \& ROPER, S. 1999. The determinants of innovation: R \& $D$, technology transfer and networking effects. Review of Industrial Organization, 15, 43-64.

MA, X. \& MCSWEENEY, P. 2008. Product and process innovation in the food processing industry: Case study in Guangxi province. Australian Agribusiness Review, 16. 
MARTÍNEZ-ROS, E. \& LABEAGA, J. M. 2009. Product and process innovation: Persistence and complementarities. European Management Review, 6, 64-75.

MASSA, S. \& TESTA, S. 2008. Innovation and SMEs: Misaligned perspectives and goals among entrepreneurs, academics, and policy makers. Technovation, 28, 393-407.

MCADAM, R., MOFFETT, S., HAZLETT, S. A. \& SHEVLIN, M. 2010. Developing a model of innovation implementation for UK SMEs: A path analysis and explanatory case analysis. International Small Business Journal, 28, 195-214.

MCADAM, R., REID, R. \& GIBSON, D. 2004. Innovation and organisational size in Irish SMEs: an empirical study. International Journal of Innovation Management, 8, 147-165.

MENRAD, K. 2004. Innovations in the food industry in Germany. Research Policy, 33, 1-18.

MOONEY, J. G., GURBAXANI, V. \& KRAEMER, K. L. 1996. A process oriented framework for assessing the business value of information technology. ACM SIGMIS Database, 27, 68-81.

NAIDOO, V. 2010. Firm survival through a crisis: The influence of market orientation, marketing innovation and business strategy. Industrial Marketing Management, 39, 1311-1320.

NAMBISAN, S. 2003. Information systems as a reference discipline for new product development. MIS Quarterly, 27, 1-18.

OKE, A., BURKE, G. \& MYERS, A. 2007. Innovation types and performance in growing UK SME's. International Journal of Operations \& Production Management, 27, 735-753.

OLSSON, A. \& LARSSON, A. C. 2009. Value creation in PSS design through product and packaging innovation processes. In: SAKAO, T. \& LINDAHL, M. (eds.) Introduction to Product/Service-System Design. London: Springer.

ORTEGA-ARGILÉS, R. \& BRANDSMA, A. 2010. EU-US differences in the size of $R \& D$ intensive firms: do they explain the overall R\&D intensity gap? Science and Public Policy, 37, 429-441.

PARIDA, V., WESTERBERG, M. \& FRISHAMMAR, J. 2012. Inbound Open Innovation Activities in High-Tech SMEs: The Impact on Innovation Performance. Journal of Small Business Management, 50, 283-309.

PULLEN, A., DE WEERD-NEDERHOF, P. C., GROEN, A. J. \& FISSCHER, O. A. M. 2012. SME network characteristics vs. product innovativeness: How to achieve high innovation performance. Creativity and Innovation Management, 21, 130-146.

RAMA, R. \& VON TUNZELMANN, N. 2009. Empirical studies of innovation in the food and beverage industry. In: RAMA, R. (ed.) Handbook of Innovation in the Food and Drink Industry. New York/London: Haworth Press.

RODGERS, S. 2008. Technological innovation supporting different food production philosophies in the food service sectors. International Journal of Contemporary Hospitality Management, 20, 19-34. 
ROWLEY, J., BAREGHEH, A. \& SAMBROOK, S. 2011. Towards an innovation-type mapping tool. Management Decision, 49, 7386.

SAUNDERS, M., LEWIS, P. \& THORNHILL, A. 2003. Research methods for business students, Harlow, Prentice Hall.

SEGARS, A. \& GROVER, V. 1993. Re-examining perceived ease of use and usefulness: A confirmatory factor analysis. MIS Quarterly, 17, 517-525.

SIGUAW, J. A., SIMPSON, P. M. \& ENZ, C. A. 2006. Conceptualizing innovation orientation: A framework for study and integration of innovation research. Journal of Product Innovation Management, 23, 556-574.

SONNEVELD, K. 2000. What drives food packaging innovation? Packaging Technology and Science, 13, 29-35.

TEECE, D. J. 2010. Business models, business strategy and innovation. Long Range Planning, 43, 172-194.

TIDD, J., BESSANT, J. \& PAVITT, K. 2005. Managing Innovation, integrating technological, market and organizational change, Chichester, John Wiley \& Sons.

TRAILL, W. B. \& MEULENBERG, M. 2002. Innovation in the food industry. Agribusiness, 18, 1-21.

VAN DE VEN, A. H., POLLEY, D. E., GARUD, R. \& VENKATARAMAN, S. 1999. The innovation journey, New York, Oxford University Press.

VAN DE VRANDE, V., DE JONG, J. P. J., VANHAVERBEKE, W. \& DE ROCHEMONT, M. 2009. Open innovation in SMEs: Trends, motives and management challenges. Technovation, 29, 423437.

VORBACH, S. \& PERL, E. 2007. Decision Making in Innovation Processes-a Concept to Support Small and Medium Sized Enterprises. Journal of Automation, Mobile Robotics \& Intelligent Systems, 1, 5-15.

WEST, J. \& GALLAGHER, S. 2006. Challenges of open innovation: the paradox of firm investment in open-source software. $R \& D$ Management, 36, 319-331.

WETHERILL, P. 2009. UK Business: Acitivity, Size and Location-2009, UK, Office for National Statistics.

WHYTE, J., BESSANT, J. \& NEELY, A. 2005. Management of creativity and design within the firm. London, UK: Department of Trade and Industry.

WISCHNEVSKY, J. D., DAMANPOUR, F. \& MENDEZ, F. A. 2011. Influence of environmental factors and prior changes on the organizational adoption of changes in products and in technological and administrative processes. British Journal of Management, 22, 132-149.

YOUNG, S. 2004. Breaking down the barriers to packaging innovation. Design Management Review, 15, 68-73.

ZAHRA, S. A. \& COVIN, J. G. 1994. The financial implications of fit between competitive strategy and innovation types and 
sources. The Journal of High Technology Management Research, 5, 183-211.

ZHANG, J. \& DUAN, Y. 2010. The impact of different types of market orientation on product innovation performance: Evidence from Chinese manufacturers. Management Decision, 48, 849-867. 